\title{
TREE-LIKE PINES ON THE MSHANA PEAT BOG IN THE GORGANY MOUNTAINS: A TRACE OF PINUS ULIGINOSA MIGRATION IN THE EAST CARPATHIANS?
}

\author{
KRYSTYNA BORATYŃSKA ${ }^{1}$, ANNA SULIKOWSKA ${ }^{2}$, DMYTRO M. IAKUSHENKO ${ }^{3}$, \\ ANNA K. JASIŃSKA ${ }^{1}$, KAROLINA SOBIERAJSKA ${ }^{1}$ \\ ${ }^{1}$ Institute of Dendrology, \\ Polish Academy of Sciences \\ Parkowa 5, 62-035 Kórnik, Poland \\ e-mail: borkrys@man.poznan.pl \\ 2 University of Life Sciences, Faculty of Forestry, \\ Department of Forestry Natural Foundations \\ Wojska Polskiego 71D, 60-625 Poznań, Poland \\ ${ }^{3}$ University of Zielona Góra, Faculty of Biological Sciences \\ Prof. Z. Szafrana 1, 65-516 Zielona Góra, Poland
}

(Received: November 24, 2009. Accepted: March 24, 2010)

\begin{abstract}
The taxonomic position of the population of tree-like, mostly polycormic individuals of pines from the Mshana peat bog in the Gorgany Mountains (East Carpathians, Ukraine) has been studied on the basis of the morphological characteristics of cones and needles, and anatomical characteristics of the needles. These features have been compared with the surrounding Pinus mugo population as well as $P$. uliginosa, $P$. mugo, $P$. sylvestris and $P$. uncinata from natural populations of the taxa. Tree-like individuals were found to have the most similar needles to $P$. uliginosa, but most similar cone characteristics to $P$. mugo. It was concluded, that the tree-like population has a relic character and can present the trace of the early migration of $P$. uliginosa from the West and its hybridisation with $P$. mugo.
\end{abstract}

KEY WORDS: Pinus uliginosa, P. mugo, P. sylvestris, P. uncinata, needle, cone, morphology, variability, taxonomy.

\section{INTRODUCTION}

Pinus uliginosa Neumann is a polycormic tree up to about 15-18 $\mathrm{m}$ high, with dark bark on the trunk and branches and large, about $3 \mathrm{~cm}$ long, asymmetric cones with hooked apophyses. It occurs in several places across the Czech Republic, south-eastern Germany, south-western Poland and northern Austria. Despite investigations on its taxonomic position it remains controversial. It has been treated as a hybrid between $P$. mugo Turra and $P$. sylvestris L. (e.g. Staszkiewicz and Tyszkiewicz 1972; Staszkiewicz 2001) or between $P$. mugo and $P$. uncinata Ramond (Christensen 1987), a synonym of $P$. rotundata Link (Businský 1999) or lately as a subspecies of $P$. uncinata (Businský and Kirschner 2006; Businský 2008). Businský (2008) suggests that the peat bog pine is the subspecies $P$. uncinata subsp. uliginosa (Neumann) Businský and this rank of the taxon has been adopted in this study.

The problems with the morphological delimitation of $P$. uncinata, $P$. uliginosa, $P$. mugo, $P$. rotundata and $P$. $\times$ rha- etica Brügger arise mainly from the hybridisation among them in the areas where these taxa occur together. Intensive hybridisation between $P$. mugo and $P$. uncinata takes place in the western Alps, and between $P$. mugo and $P$. uliginosa in the low mountains north of the Alps (Christensen 1987; Christensen and Dar 1997, 2003; Businský 1999, 2008; Boratyńska et al. 2003; Kormuták et al. 2005; Wachowiak and Prus-Głowacki 2008). The latter taxon, $P$. uliginosa, belongs to rare plants connected with central Europe. Most localities of $P$. uliginosa are endangered because of the disappearance of peat bogs, where this species grows (Gołąb 1999; Businský 1999; Danielewicz and Zieliński 2000; Mach et al. 2009; Bastl et al. 2009). This also concerns localities protected in nature reserves or national parks (Businský 1999; Gołąb 1999; Danielewicz and Zieliński 2000; Staszkiewicz 2001). The easternmost isolated localities of $P$. uliginosa have been recorded in the Eastern Carpathians. The occurrence of the species had been described in the Pogórze Przemyskie (Schramm 1925), but two localities in that region have since disappeared 
(Schramm 1973; Staszkiewicz 2001). Specimens resembling $P$. uliginosa have also been described in the peat bog near Dolina at the northern base of the Eastern Beskids (Windakiewicz 1873) and in the Kikhola peat bog in the Gorgany Mountains (Trampler 1937), but neither has recently been confirmed (Tsaryk et al. 2006). Finding several tree-like, polycormic individuals of pines resembling $P$. uliginosa in the Mshana peat bog in the Gorgany Mountains (Jasińska et al. 2009), about $350 \mathrm{~km}$ south-east of existing localities of the species in the Nowy Targ Basin (Kotlina Nowotarska) shall be treated as very interesting in case of confirmation of their taxonomical position.

The aims of this study were: 1) to verify the influence of the tree-like versus shrubby growth form to the morphological characteristics of cones and morphological and anatomical characteristics of needles; and 2) to test the taxonomic status of the tree-like specimens of mountain pine from the Mshana peat bog using the morphological characteristics of the cones and morphological and anatomical characteristics of the needles (Szweykowski 1969; Staszkiewicz and Tyszkiewicz 1972; Boratyńska and Bobowicz 2000; Boratyńska and Boratyński 2007; Marcysiak and Boratyński 2007; Boratyńska and Lewandowska 2009).

\section{MATERIALS AND METHODS}

\section{Materials}

The partly drained Mshana peat bog ("Boloto Mshana") in the Gorgany Mountains is located in the valley of the Mshana stream near Osmoloda, at an altitude of $830 \mathrm{~m}$ and surrounded by extensive Norway spruce forest with admixture of Betula pendula Roth (Table 1). Only 16 tree-like

TABLE 1. Tree-like pines from the Mshana peat bog and comparative material of $P$. mugo, P. uncinata and P. uliginosa.

\begin{tabular}{|c|c|c|c|c|c|c|}
\hline Taxon & Locality & Acronym & Geographic coordinates & Altitude (m) & Subject & Source of data \\
\hline Pinus & $\begin{array}{l}\text { Ukraine, Carpathians, Gorgany Mts, } \\
\text { Osmoloda, Mshana peat bog }\end{array}$ & PN & $48^{\circ} 40^{\prime} 33^{\prime}$ 'N 2355'19''E & 830 & $\begin{array}{l}\text { needles, } \\
\text { cones }\end{array}$ & This paper \\
\hline \multirow[t]{5}{*}{$\begin{array}{l}\text { Pinus } \\
\text { mugo }\end{array}$} & $\begin{array}{l}\text { Ukraine, Carpathians, Gorgany Mts, } \\
\text { Osmoloda, Mshana peat bog }\end{array}$ & M_1 & $48^{\circ} 40^{\prime} 33^{\prime \prime} \mathrm{N} 23^{\circ} 55^{\prime} 19^{\prime \prime} \mathrm{E}$ & 830 & $\begin{array}{l}\text { needles, } \\
\text { cones }\end{array}$ & This paper \\
\hline & $\begin{array}{l}\text { Ukraine, Carpathians, Chornokhora Mts, } \\
\text { N slopes of Khoverla }\end{array}$ & M_3 & $48^{\circ} 08^{\prime} 00^{\prime \prime} \mathrm{N} 24^{\circ} 37^{\prime} 30^{\prime \prime} \mathrm{E}$ & 1550 & cones & Marcysiak and Boratyński 2007 \\
\hline & $\begin{array}{l}\text { Poland, Carpathians, Tatry Mts, } \\
\text { Dolina Pięciu Stawów }\end{array}$ & M_4 & $49^{\circ} 13^{\prime} 09^{\prime \prime} \mathrm{N} 20^{\circ} 03^{\prime} 05^{\prime \prime} \mathrm{E}$ & 1700 & needles & Boratyńska et al. 2004 \\
\hline & $\begin{array}{l}\text { Poland, Carpathians, Tatry Mts, } \\
\text { Grześ-Wołowiec ridge }\end{array}$ & M_5 & $49^{\circ} 13^{\prime} 07^{\prime \prime} \mathrm{N} 19^{\circ} 45^{\prime} 50^{\prime \prime} \mathrm{E}$ & 1620 & cones & Marcysiak and Boratyński 2007 \\
\hline & $\begin{array}{l}\text { Poland, Sudetes, Karkonosze Mts, } \\
\text { Czarny Kocioł Jagniątkowski }\end{array}$ & M_6 & $50^{\circ} 47^{\prime} 05^{\prime \prime} \mathrm{N} 15^{\circ} 35^{\prime} 30^{\prime \prime} \mathrm{E}$ & 1350 & needles & $\begin{array}{l}\text { Sobierajska } \\
\text { and Boratyńska } 2010\end{array}$ \\
\hline \multirow[t]{4}{*}{$\begin{array}{l}\text { Pinus } \\
\text { uliginosa }\end{array}$} & $\begin{array}{l}\text { Poland, Sudetes, Karkonosze Mts, } \\
\text { Kocioł Małego Stawu }\end{array}$ & M_7 & $50^{\circ} 44^{\prime} 41^{\prime \prime} \mathrm{N} 15^{\circ} 47^{\prime} 34^{\prime \prime} \mathrm{E}$ & 1380 & cones & $\begin{array}{l}\text { Sobierajska } \\
\text { and Boratyńska } 2010\end{array}$ \\
\hline & $\begin{array}{l}\text { Poland, Sudetes, Stołowe Mts, } \\
\text { Batorów peat bog }\end{array}$ & UL_1 & $50^{\circ} 27^{\prime} 36^{\prime \prime} \mathrm{N} 16^{\circ} 15^{\prime} 25^{\prime \prime} \mathrm{E}$ & 750 & needles & Boratyńska et al. 2003 \\
\hline & $\begin{array}{l}\text { Poland, Bory Dolnośląskie, } \\
\text { Nature Reserve Węgliniec }\end{array}$ & UL_2 & $51^{\circ} 17^{\prime} 50^{\prime \prime} \mathrm{N} 16^{\circ} 15^{\prime} 25^{\prime \prime} \mathrm{E}$ & 200 & $\begin{array}{l}\text { needles, } \\
\text { cones }\end{array}$ & $\begin{array}{l}\text { Marcysiak et al. } 2003 ; \\
\text { Boratyńska et al. } 2003\end{array}$ \\
\hline & $\begin{array}{l}\text { Poland, Bory Dolnośląskie, } \\
\text { Węglowiec }\end{array}$ & UL_3 & $51^{\circ} 18^{\prime} 61^{\prime \prime} \mathrm{N} 15^{\circ} 11^{\prime} 34^{\prime \prime} \mathrm{E}$ & 200 & needles & $\begin{array}{l}\text { Sobierajska and } \\
\text { Boratyńska 2008; Boratyńska } \\
\text { and Lewandowska } 2009\end{array}$ \\
\hline \multirow[t]{2}{*}{$\begin{array}{l}\text { Pinus } \\
\text { uncinata }\end{array}$} & Andora, Pyrenees, Vall de Ransol & UN_1 & $42^{\circ} 37^{\prime} 30^{\prime \prime} \mathrm{N} 01^{\circ} 35^{\prime} 37^{\prime \prime} \mathrm{E}$ & 2025 & $\begin{array}{l}\text { needles, } \\
\text { cones }\end{array}$ & $\begin{array}{l}\text { Boratyńska and Boratyński } \\
\text { 2007; Boratyńska et al. } 2004\end{array}$ \\
\hline & Spain, Pyrenees, Vall de Nuria & UN_2 & $42^{\circ} 22^{\prime} 40^{\prime \prime} \mathrm{N} 02^{\circ} 10^{\prime} 49^{\prime \prime} \mathrm{E}$ & 2150 & cones & Marcysiak and Boratyński 2007 \\
\hline \multirow[t]{3}{*}{$\begin{array}{l}\text { Pinus } \\
\text { sylvestris }\end{array}$} & $\begin{array}{l}\text { Poland, Sudetes, Stołowe Mts, } \\
\text { Szczeliniec Wielki Mt. }\end{array}$ & S_1 & $50^{\circ} 28^{\prime} 55^{\prime \prime} \mathrm{N} 16^{\circ} 16^{\prime} 46^{\prime \prime} \mathrm{E}$ & 900 & needles & $\begin{array}{l}\text { Boratyńska } \\
\text { and Lewandowska } 2009\end{array}$ \\
\hline & $\begin{array}{l}\text { Poland, Bory Tucholskie Forest, } \\
\text { Krówka }\end{array}$ & S_2 & $53^{\circ} 21^{\prime} 42^{\prime \prime} \mathrm{N} 17^{\circ} 52^{\prime} 16^{\prime \prime} \mathrm{E}$ & 90 & cones & Marcysiak and Boratyński 2007 \\
\hline & $\begin{array}{l}\text { Poland, Bory Dolnośląskie Forest, } \\
\text { Węgliniec }\end{array}$ & S_3 & $51^{\circ} 18^{\prime} 61^{\prime \prime} \mathrm{N} 15^{\circ} 11^{\prime} 34^{\prime \prime} \mathrm{E}$ & 200 & needles & Boratyńska et al. 2003 \\
\hline
\end{tabular}


TABLE 2. Result of Student's $t$-test for characters of needles and cones from two samples from the Mshana peat bog: PN (type $P$. uliginosa) and M_1 (type $P$. mugo).

\begin{tabular}{|c|c|c|c|c|c|}
\hline \multirow{2}{*}{ Character } & \multicolumn{2}{|c|}{ Arithmetical means } & \multirow{2}{*}{$\mathrm{t}$} & \multirow{2}{*}{ df } & \multirow{2}{*}{$\mathrm{p}$} \\
\hline & M_1 & PN & & & \\
\hline 1. Needle length $(\mathrm{mm}) *$ & 35.65 & 37.41 & -0.83 & 42 & 0.412 \\
\hline 2. Number of stomatal rows on the convex (abaxial) side of needle & 8.34 & 7.59 & 2.88 & 42 & 0.006 \\
\hline 3. Number of stomatal rows on the flat (adaxial) side of needle & 5.34 & 5.08 & 1.45 & 42 & 0.153 \\
\hline 4. Number of stomata on a $2 \mathrm{~mm}$ long section of needle, on the convex (abaxial) side $*$ & 19.00 & 18.17 & 2.44 & 42 & 0.019 \\
\hline 5. Number of stomata on a $2 \mathrm{~mm}$ long section of needle, on the flat (adaxial) side $*$ & 18.84 & 17.74 & 3,37 & 42 & 0.002 \\
\hline 6. Number of resin canals $*$ & 3.49 & 2.78 & 3.93 & 42 & 0.000 \\
\hline 7. Needle width $(\mu \mathrm{m})$ & 1191.75 & 1221.60 & -1.07 & 42 & 0.289 \\
\hline 8. Needle thickness $(\mu \mathrm{m})$ & 742.53 & 746.19 & -0.23 & 42 & 0.819 \\
\hline 9. Distance between vascular bundles $(\mu \mathrm{m})$ & 80.78 & 92.11 & -1.28 & 42 & 0.207 \\
\hline 10. Height (thickness) of epidermial cells ( $\mu \mathrm{m})$ & 34.01 & 34.52 & -0.50 & 42 & 0.620 \\
\hline 11. Width of epidermal with hypodermal cells $(\mu \mathrm{m})$ & 15.69 & 16.01 & -0.91 & 42 & 0.366 \\
\hline 12. Width of epidermal cells $(\mu \mathrm{m})$ & 23.25 & 23.98 & -0.81 & 42 & 0.421 \\
\hline 13. Width of hypodermal cells $(\mu \mathrm{m})$ & 10.76 & 10.60 & 0.46 & 42 & 0.648 \\
\hline 14. Number of sclerenchymatic cells layer over the vascular bundles & 1.42 & 0.84 & 4.28 & 42 & 0.000 \\
\hline 15. Marcet's coefficient (=traits $9 \times 7 / 8) *$ & 130.51 & 151.59 & -1.40 & 42 & 0.170 \\
\hline 16. Stomatal rows ratio $(=$ traits $2 / 3) *$ & 1.60 & 1.53 & 1.60 & 42 & 0.118 \\
\hline 17. Stomata ratio $(=$ traits $4 / 5)$ & 1.01 & 1.03 & -1.57 & 42 & 0.124 \\
\hline 18. Needle thickness/width ratio (=traits $8 / 7)^{*}$ & 0.62 & 0.61 & 1.69 & 42 & 0.099 \\
\hline 19. Epidermis with hypodermis cells width/thickness ratio (=traits $11 / 10) *$ & 0.47 & 0.47 & -0.12 & 42 & 0.901 \\
\hline 20. Epidermis cell width/thickness ratio (=traits $12 / 10)$ & 0.69 & 0.68 & 0.37 & 42 & 0.712 \\
\hline \multicolumn{6}{|l|}{ 21. Character of cells between vascular bundles $(\%)^{*}$} \\
\hline A - fibre-like cells & 4.09 & 0.98 & 1.38 & 42 & 0.176 \\
\hline $\mathrm{B}$ - intermediate, semi-fibrous cells & 9.50 & 17.82 & -1.66 & 42 & 0.105 \\
\hline $\mathrm{C}$ - intermediate & 32.24 & 54.45 & -4.80 & 42 & 0.000 \\
\hline D - cells with thin walls and large lumens & 54.11 & 26.96 & 3.73 & 42 & 0.001 \\
\hline \multicolumn{6}{|l|}{ 22. Character of cells around the resin canals $(\%)^{*}$} \\
\hline A - fibre-like cells & 33.19 & 70.79 & -5.44 & 42 & 0.000 \\
\hline $\mathrm{B}$ - intermediate cells & 48.51 & 28.13 & 4.73 & 42 & 0.000 \\
\hline $\mathrm{C}-$ cells with thin walls and large lumens & 17.96 & 1.08 & 3.25 & 42 & 0.002 \\
\hline 23. Length of cone (mm) & 31.13 & 30.53 & -0.42 & 42 & 0.678 \\
\hline 24. Maximal diameter of cone $(\mathrm{mm})$ & 17.82 & 19.35 & 2.63 & 42 & 0.012 \\
\hline 25. Cone scale number & 82.81 & 86.94 & 1,58 & 42 & 0.120 \\
\hline 26. Length of cone scale apophysis (mm) & 5.69 & 5.91 & 0.88 & 42 & 0.386 \\
\hline 27. Width of cone scale apophysis (mm) & 6.85 & 6.34 & -2.14 & 42 & 0.038 \\
\hline 28. Thickness of cone apophysis (mm) & 1.85 & 2.26 & 6.07 & 42 & 0.000 \\
\hline 29. Distance between umbo and scale top $(\mathrm{mm}) *$ & 3.01 & 3.07 & 0.41 & 42 & 0.685 \\
\hline 30. Diameter of cone top $(\mathrm{mm}) *$ & 4.68 & 4.73 & 0.34 & 42 & 0.739 \\
\hline 31. Diameter of cone midpoint between the top and maximal diameter $(\mathrm{mm}) *$ & 14.20 & 14.70 & 1.10 & 42 & 0.278 \\
\hline 32. Measurement of convex cone side from stalk to top (mm) & 45.74 & 45.64 & -0.06 & 42 & 0.955 \\
\hline 33. Measurement of concave cone side from stalk to top (mm) & 40.78 & 40.57 & -0.13 & 42 & 0.896 \\
\hline 34. Ratio of cone length/maximal diameter $(23 / 24) *$ & 1.74 & 1.57 & -3.76 & 42 & 0.001 \\
\hline 35. Ratio of cone length/number of scales $(23 / 25) *$ & 0.38 & 0.36 & -1.36 & 42 & 0.182 \\
\hline 36. Ratio of cone scale apophysis length/width $(26 / 27) *$ & 0.84 & 0.93 & 3.77 & 42 & 0.001 \\
\hline 37. Ratio of cone scale apophysis length/thickness $(26 / 28) *$ & 3.14 & 2.67 & -3.40 & 42 & 0.001 \\
\hline 38. Cone asymmetry (ratio of convex/concave cone measurements, 32/33) * & 1.13 & 1.14 & 0.52 & 42 & 0.607 \\
\hline
\end{tabular}

*characters used in discriminant and cluster analyses

specimens resembling peat bog pines were found there, surrounded by numerous shrubby individuals, typical of $P$. mugo (Jasińska et al. 2009). Material was collected separately from tree-like and shrubby individuals, the first as tree-like pines (PN) and the second as P. mugo (M_1). Ten two-year-old dwarf shoots (brachyblasts) from the central part of a long shoot with undamaged needles and ten mature cones were gathered from each individual according to the methods described earlier (Boratyńska and Bobowicz 2000; Boratyńska et al. 2003). Some tree-like individuals were in a bad condition or had only a few cones. Finally, 14 individuals were represented in needle samples and 15 in cone samples and 140 needles and 86 cones have been gathered. Similarly, following the sampling method described by Boratyńska et al. (2003) altogether, 300 needles and 248 cones were collected from 30 individuals of a $P$. mugo population. Sampled individuals were separated by distances of least $40 \mathrm{~m}$ to avoid collecting from the same genet.

The tree-like pines and Pinus mugo from the Mshana peat bog were biometrically compared with another populations of $P$. mugo and with closely related $P$. uncinata, $P$. uliginosa and $P$. sylvestris using data from previously published works (source of data in Table 1). The comparative material included: three samples of $P$. mugo needles and five of cones from the Carpathians in Poland and Ukraine and the Sudetes in Poland, three samples of $P$. uliginosa needles and one of cones from the Sudetes and lowland in Poland; one sample of $P$. uncinata needles and two of cones from the Pyrenees in Spain and Andorra; and two samples of $P$. sylvestris needles and one of cones from the Sudetes and lowland in Poland (Table 1). 

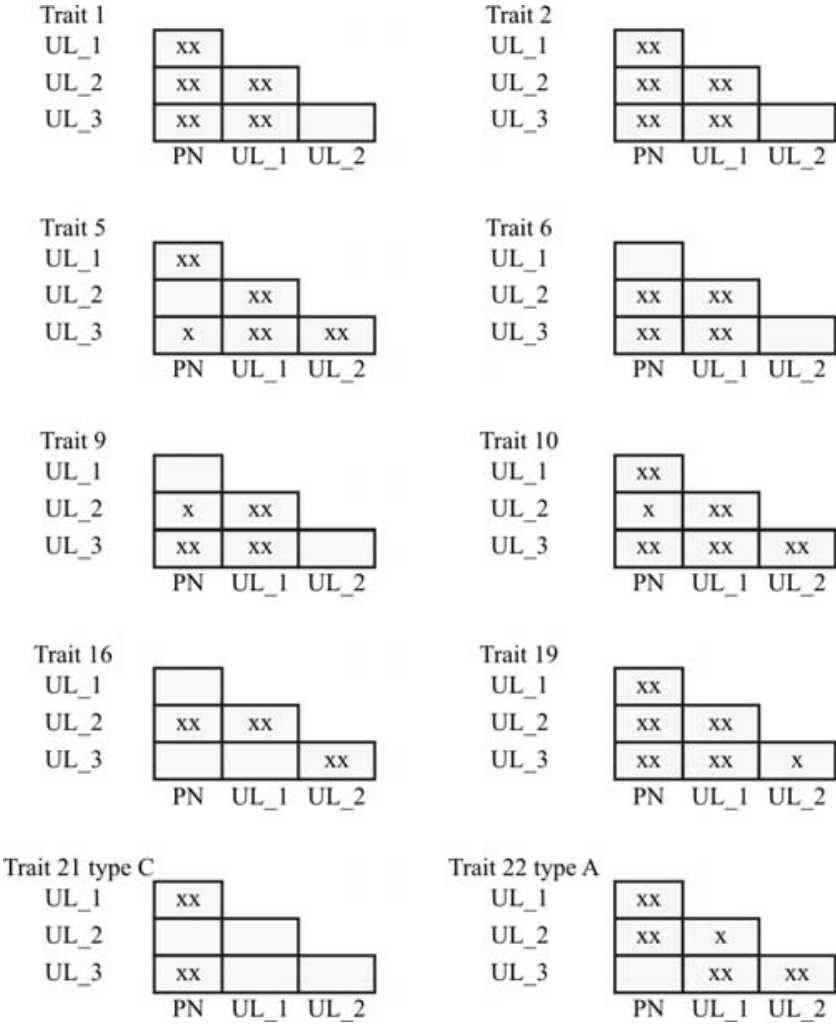

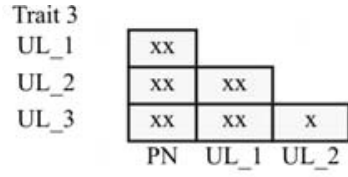

Trait 4

UL_1

UL_2

UL_3

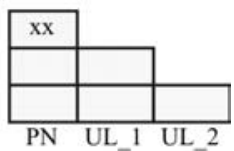

Trait 7

UL_1

UL_2

UL_3

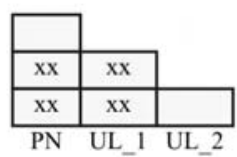

Trait 8

UL_1

UL_2

UL_3

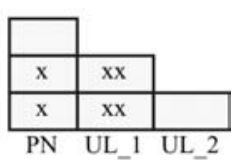

Trait 11

UL_1

UL_2

UL_3

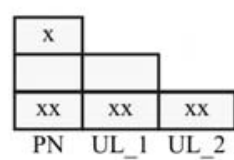

Trait 15

UL_1

UL_2

UL_3
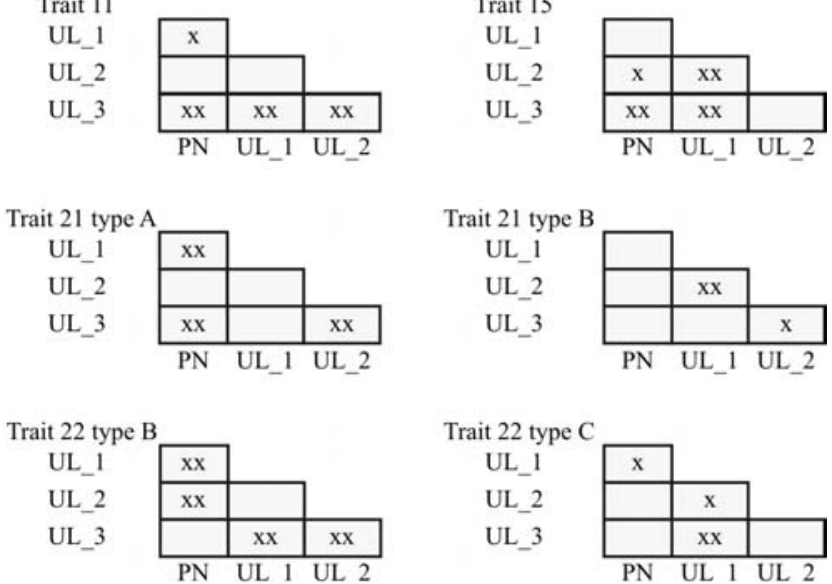

Fig. 1. Student's $t$-test differences between verified tree-like pines from the Mshana peat bog (PN) and three Sudetan populations of Pinus uliginosa (UL_1, UL_2 and UL_3, acronyms as in table 1); $\mathrm{x}$ - differences statistically significant at $\mathrm{p}=0.05$, $\mathrm{xx}-$ differences statistically significant at $\mathrm{p}=0.01$.

\section{Biometrical measurements}

The 22 traits of needles and 16 of cones were measured and/or evaluated (Table 2) following procedures and using methods described in previous works (Szweykowski 1969; Staszkiewicz and Tyszkiewicz 1969, 1972; Boratyńska and Bobowicz 2000; Marcysiak et al. 2003; Marcysiak 2004; Marcysiak and Boratyński 2007; Boratyńska and Boratyński 2007; Boratyńska et al. 2009).

\section{Statistical treatment}

The arithmetic means, standard deviations and coefficients of variation were calculated and analysed. The values of particular characters between the two samples from the Mshana Peat-bog in the Gorgany Mountains were compared using the Student's $t$-test for independent samples to testify the differences between them. Discriminant analysis was performed and the position of individuals from the particular subpopulations and samples from the Sudetes and Carpathians was examined along the first two discriminant variables to show the intra- and interpopulational variation (Sokal and Rohlf 2003; Stanisz 2007). Cluster analysis based on the shortest Euclidean distances, following the unweighted pair group average (UPGMA), was also used to verify the findings (Sokal and Rohlf 2003). The distribution of every trait was checked using the ShapiroWilks test and those characterised with biased distribution were transformed to fulfil the demands of multivariate analyses. The values of every trait were standardised prior to analyses. The percentage data were arcsine transformed prior to statistical analyses (Watała 2002). STATISTICA PL 7.0 for Windows (StatSoft) was used in the calculations.

\section{RESULTS}

Tree-like pines versus Pinus mugo from the Mshana peat bog

The traits of the tree-like pines (PN) and P. mugo (M_1) on the Mshana peat bog in the Gorgany Mountains differ at statistically significant level in respect to several traits (Table 2). The highest differences were found in the number of the strata of sclerenchyma cells above the phloem on the needle cross-section (character 14). Statistically significant

TABLE 3. Result of Student's $t$-test for cone characters of tree-like pines from the Mshana peat bog (PN) and Pinus uliginosa from Weggliniec Nature Reserve (UL_2).

\begin{tabular}{lccccc}
\hline & \multicolumn{2}{l}{ Arithmetical means } & & & \\
\cline { 2 - 3 } Character & & $\mathrm{t}$ & $\mathrm{df}$ & $\mathrm{p}$ \\
\cline { 2 - 4 } & $\mathrm{UL} 2$ & $\mathrm{PN}$ & & & \\
\hline 23 & 33.26 & 30.53 & 1.90 & 59 & 0.063 \\
24 & 16.85 & 19.35 & -4.19 & 59 & 0.000 \\
25 & 75.35 & 86.94 & -4.29 & 59 & 0.000 \\
26 & 6.84 & 5.91 & 3.31 & 59 & 0.002 \\
27 & 7.03 & 6.34 & 3.36 & 59 & 0.001 \\
28 & 3.71 & 2.26 & 6.48 & 59 & 0.000 \\
29 & 4.37 & 3.07 & 5.89 & 59 & 0.000 \\
30 & 3.35 & 4.73 & -9.64 & 59 & 0.000 \\
31 & 12.31 & 14.7 & -4.61 & 59 & 0.000 \\
32 & 48.47 & 45.64 & 1.53 & 59 & 0.131 \\
33 & 34.75 & 40.57 & -3.55 & 59 & 0.001 \\
34 & 1.99 & 1.57 & 8.30 & 59 & 0.000 \\
35 & 0.45 & 0.36 & 5.06 & 59 & 0.000 \\
36 & 0.98 & 0.93 & 1.38 & 59 & 0.174 \\
37 & 1.98 & 2.67 & -4.52 & 59 & 0.000 \\
38 & 1.42 & 1.14 & 6.26 & 59 & 0.000 \\
\hline
\end{tabular}


TABLE 4. Discriminant power testing for needle characters of tree-like pines from the Mshana peat bog, $P$. mugo, $P$. uliginosa, $P$. uncinata and $P$. sylvestris.

\begin{tabular}{|c|c|c|c|c|}
\hline No & Character & Partial Wilks' lambda & $F$ statisti & $P$ value \\
\hline 1 & Needle length & 0.6580 & 16.22 & 0.0000 \\
\hline 4 & Number of stomata on a $2 \mathrm{~mm}$ long section of needle, on the convex (abaxial) side & 0.9025 & 3.37 & 0.0006 \\
\hline 5 & Number of stomata on a $2 \mathrm{~mm}$ long section of needle, on the flat (adaxial) side & 0.8941 & 3.70 & 0.0002 \\
\hline 6 & Number of resin canals & 0.8178 & 6.96 & 0.0000 \\
\hline 15 & Marcet's coefficient (=traits $9 \times 7 / 8)$ & 0.8965 & 3.60 & 0.0003 \\
\hline 16 & Stomatal rows ratio $(=$ traits $2 / 3)$ & 0.6043 & 20.44 & 0.0000 \\
\hline 18 & Needle thickness/width ratio (=traits $8 / 7$ ) & 0.7437 & 10.76 & 0.0000 \\
\hline 19 & Epidermis with hypodermis cells width/thickness ratio (=traits $11 / 10)$ & 0.4087 & 45.18 & 0.0000 \\
\hline $21 \mathrm{~A}$ & Percentage of fibre-like cells between vascular bundles & 0.7426 & 10.82 & 0.0000 \\
\hline 21B & Percentage of intermediate, semi-fibrous cells between vascular bundles & 0.6889 & 14.10 & 0.0000 \\
\hline $21 \mathrm{C}$ & Percentage of intermediate cells between vascular bundles & 0.7943 & 8.09 & 0.0000 \\
\hline $21 \mathrm{D}$ & Percentage of cells with thin walls and large lumens between vascular bundles & 0.7730 & 9.17 & 0.0000 \\
\hline $22 \mathrm{~A}$ & Percentage of fibre-like cells around resin canals & 0.7460 & 10.63 & 0.0000 \\
\hline 22B & Percentage of intermediate cells around resin canals & 0.7000 & 13.40 & 0.0000 \\
\hline $22 \mathrm{C}$ & Percentage of cells with thin walls and large lumens around resin canals & 0.6562 & 16.36 & 0.0000 \\
\hline
\end{tabular}

differences were also found in the number of resin canals, the numbers of stomata and stomata rows and percentages of particular types of sclerenchymatic cells between vascular bundles and around resin canals (characters 6, 5, 2, $21 \mathrm{C}, 21 \mathrm{D}$ and $22 \mathrm{~A}, 22 \mathrm{~B}$ and $22 \mathrm{C}$, respectively). Among the analysed characters of cones the thickness of the apophysis of cone scale (character 28) revealed the biggest differences. The cones from tree-like individuals with thicker apophyses were more rounded and showed a larger diameter (characters 36, 37, 34 and 24, respectively) than those of $P$. mugo (Table 2).

\section{Tree-like pines from the Mshana peat bog versus $P$. uliginosa from Poland}

Most of the tested characters of needles and cones from the tree-like pines from the Mshana peat bog differed from all three populations of Pinus uliginosa from Poland (Fig. 1). Only needle shape and percentage of thin walled cells between the vascular bundles (characters 18 and 21D) do not differentiate them. Insignificant differences were also found in the number of stomata on the convex needle side (character 4), but only between the tree-like pine from the Mshana peat bog and $P$. uliginosa populations from the Batorów peat bog (populations PN and UL_1) (Fig. 1).

The cones from the tree-like pines from the Mshana peat bog in the Gorgany Mountains (PN) did not differ from the cones of the $P$. uliginosa population from the Wegliniec Nature Reserve (the only cones available) in respect to cone length, measurement of cone convex side from stalk to top and shape of cone scale apophysis (characters 23, 32 and 36, respectively). All other characters differed significantly from the characters of compared populations. The tree-like pines from the Gorgany Mountains had cones with a higher number of cone scales (character 25), whereas the scale dimensions (characters 26, 27 and 28) were significantly smaller than in Bory Dolnośląskie. Additionally, the cones of tree-like population from the Gorgany were thinner (characters 24, 30 and 31), more rounded (character 34) and less asymmetric (character 38) than the population of $P$. uliginosa (Table 3).

\section{Tree-like pines from the Mshana peat bog versus $P$. uncinata, $P$. mugo, $P$. uliginosa and $P$. sylvestris}

Discriminant analysis on the 10 needle characters (Table 2) of tree-like pines from Mshana peat bog in the Gorgany
Mountains and the three populations of $P$. mugo (including the population of shrubby individuals from the Mshana peat bog), the three populations of $P$. uliginosa, one of $P$. uncinata and two of $P$. sylvestris showed that the shape of epidermis and hypodermis cells, stomatal row ratio, percentage of sclerenchyma cells with thin walls around resin canals and needle length (characters 19, 16, 22C and 1, respectively) differed at the highest level (Table 4).

The shape of epidermis and hypodermis cells, percentage of fibre-like cells between vascular bundles and number of resin canals (characters $19,21 \mathrm{~A}$ and 6 , respectively) determined at the highest level of the first discrimination variable $\left(\mathrm{U}_{1}\right)$, which was responsible for almost $61 \%$ of the total variation. This differentiated the needles of $P$. sylvestris from the needles of $P$. mugo, $P$. uncinata and $P$. uliginosa (Fig. 2A). The second discriminant variable, responsible for only $15 \%$ of the variation, was mostly determined by the percentage of thin walled cells around the resin canals, the shape of the needle cross-section and shape of epidermis cells (characters 22C, 18 and 19, respectively). The $\mathrm{U}_{2}$ discriminant variable differentiated among populations of $P$. uliginosa, $P$. uncinata and $P$. mugo. Tree-like pines population from Mshana peat bog (PN) seemed closest to the group formed by all $P$. uliginosa populations (UL_1 UL_3), but, surprisingly, the population of $P$. mи go from Mshana (M_1) also entered this group (Fig. 2A). The latter population is characterised additionally by a broad scale of variation overlapping part of the ranges of the variation of P. mugo, P. uncinata and P. uliginosa (Fig. 2A).

The UPGMA dendrogram constructed on the shortest Euclidean distances between the centroids of the compared populations confirmed the close connection between treelike pines and shrubs of $P$. mugo from the Mshana peat bog and their affinities to $P$. uliginosa, but not to $P$. mugo (Fig. 2B). It also confirmed the largest distance of $P$. uncinata from all other taxa of the $P$. mugo complex as well as the separateness of the $P$. sylvestris populations.

Discriminant analysis of eight cone characters (Table 2) of tree-like pines from Mshana peat bog in the Gorgany Mountains and five populations of $P$. mugo (including the population of shrubby individuals from the Mshana peat bog), one population of $P$. uliginosa, two of $P$. uncinata and one of $P$. sylvestris showed that the distance between the top of cone scale and umbo, cone top diameter and shape of apophysis (characters 29, 30, 36 and 37, respectively) 


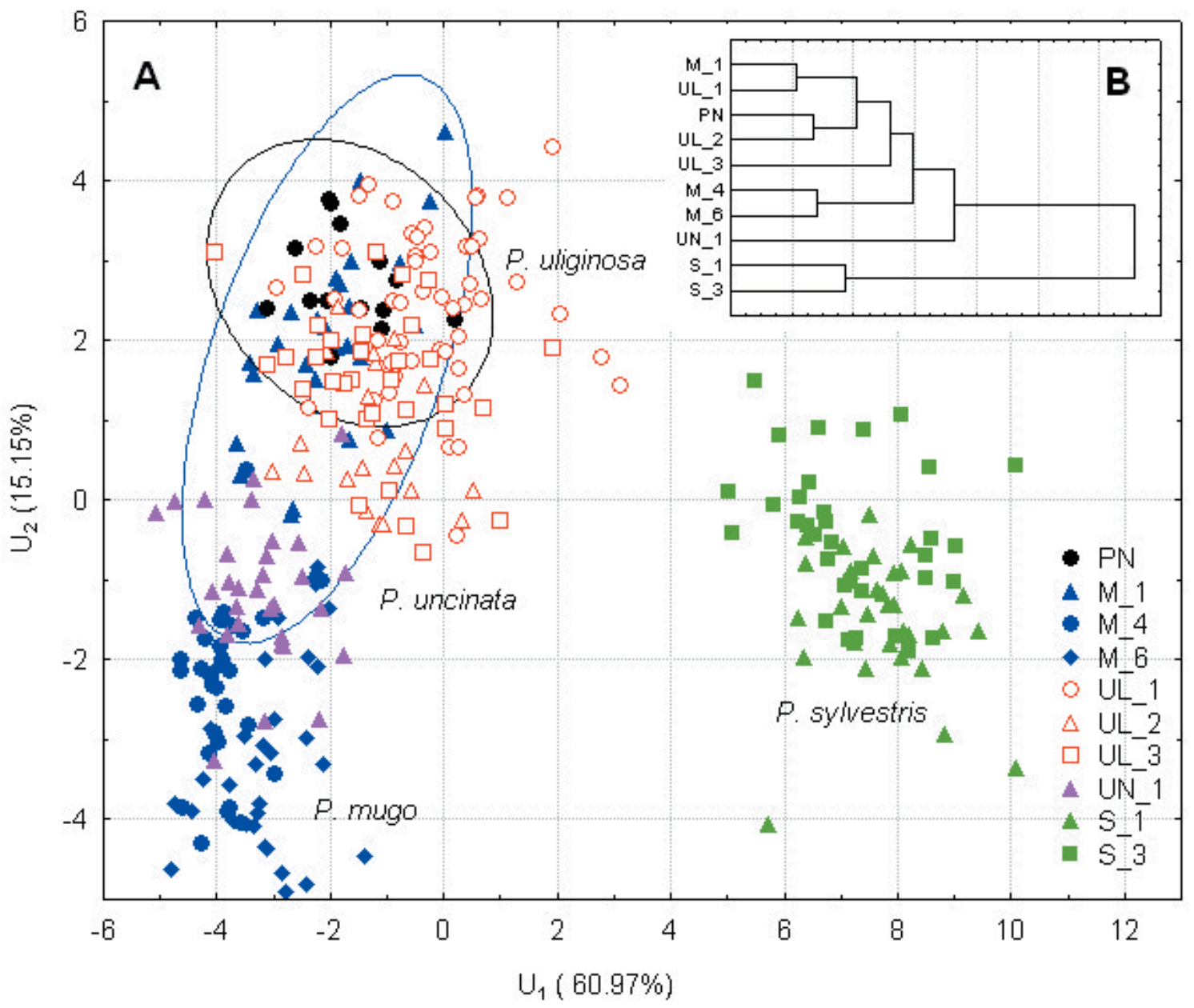

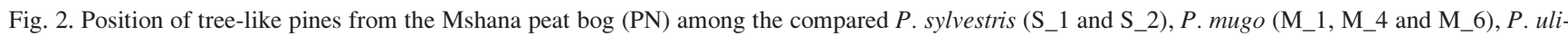
ginosa (UL_1, UL_2 and UL_3) and $P$. uncinata (UN_1) populations on the scatter-plot showing results of discriminant analysis (A) and on the dendrogram constructed on the shortest Euclidean distances according to Ward's method (B), based on the needle characters.

differentiated among them at the highest level (Table 5). All other characters discriminated among the analysed taxa and populations at a somewhat lower but still highly statistically significant level.

The two populations of Pinus uncinata were clearly distinct from the others, according to the space determined by the first two discriminant variables $\mathrm{U}_{1}$ and $\mathrm{U}_{2}$ (Fig. 3A), which were responsible for about $74 \%$ of the total variation. Both populations of $P$. uncinata were separated by the first variable, which covers more than $56 \%$ of the variation. This was determined mostly by distance from the cone scale top to umbo, cone diameter at the midpoint between the top and maximal diameter and cone asymmetry (characters 29, 31 and 38, respectively). The second discri- minant variable $\mathrm{U}_{2}$ was responsible for more than $17 \%$ of variation and was determined mostly by cone diameter at the top and at the midpoint between the top and maximal diameter than by cone and cone scale apophysis or shape and ratio of cone length/number of cone scales (characters 30, 31, 34, 36 and 35, respectively). The second discriminant variable differentiated $P$. uliginosa (UL_3), $P$. sylvestris (S_2) and P. mugo (M_1, M_2, M_3, M_5 and M_7). The population of tree-like pines from the Mshana peat bog seemed most close to the populations of $P$. mugo from the same place than to other $P$. mugo populations, and not to $P$. uliginosa (Fig. 3A).

This result is confirmed by UPGMA dendrogram constructed on the Euclidean distances from the centroids of

TABLE 5. Discriminant power testing for cone characters of tree-like pines from the Mshana peat bog, $P$. mugo, $P$. uliginosa, $P$. uncinata and $P$. sylvestris.

\begin{tabular}{|c|c|c|c|c|}
\hline No & Character & Partial Wilks' lambda & $F$ statisti & $P$ value \\
\hline 29 & Distance between umbo and scale top & 0.4399 & 53.06 & 0.0000 \\
\hline 30 & Diameter of cone top & 0.5542 & 33.51 & 0.0000 \\
\hline 31 & Diameter of cone midpoint between the top and maximal diameter & 0.6063 & 27.06 & 0.0000 \\
\hline 34 & Ratio of cone length/maximal diameter $(23 / 24)$ & 0.6868 & 19.01 & 0.0000 \\
\hline 35 & Ratio of cone length/number of scales $(23 / 25)$ & 0.6256 & 24.94 & 0.0000 \\
\hline 36 & Ratio of cone scale apophysis length/width $(26 / 27)$ & 0.5866 & 29.34 & 0.0000 \\
\hline 37 & Ratio of cone scale apophysis length/thickness $(26 / 28)$ & 0.6041 & 27.31 & 0.0000 \\
\hline 38 & Cone asymmetry (ratio of convex/concave cone measurements, 32/33) & 0.6393 & 23.51 & 0.0000 \\
\hline
\end{tabular}




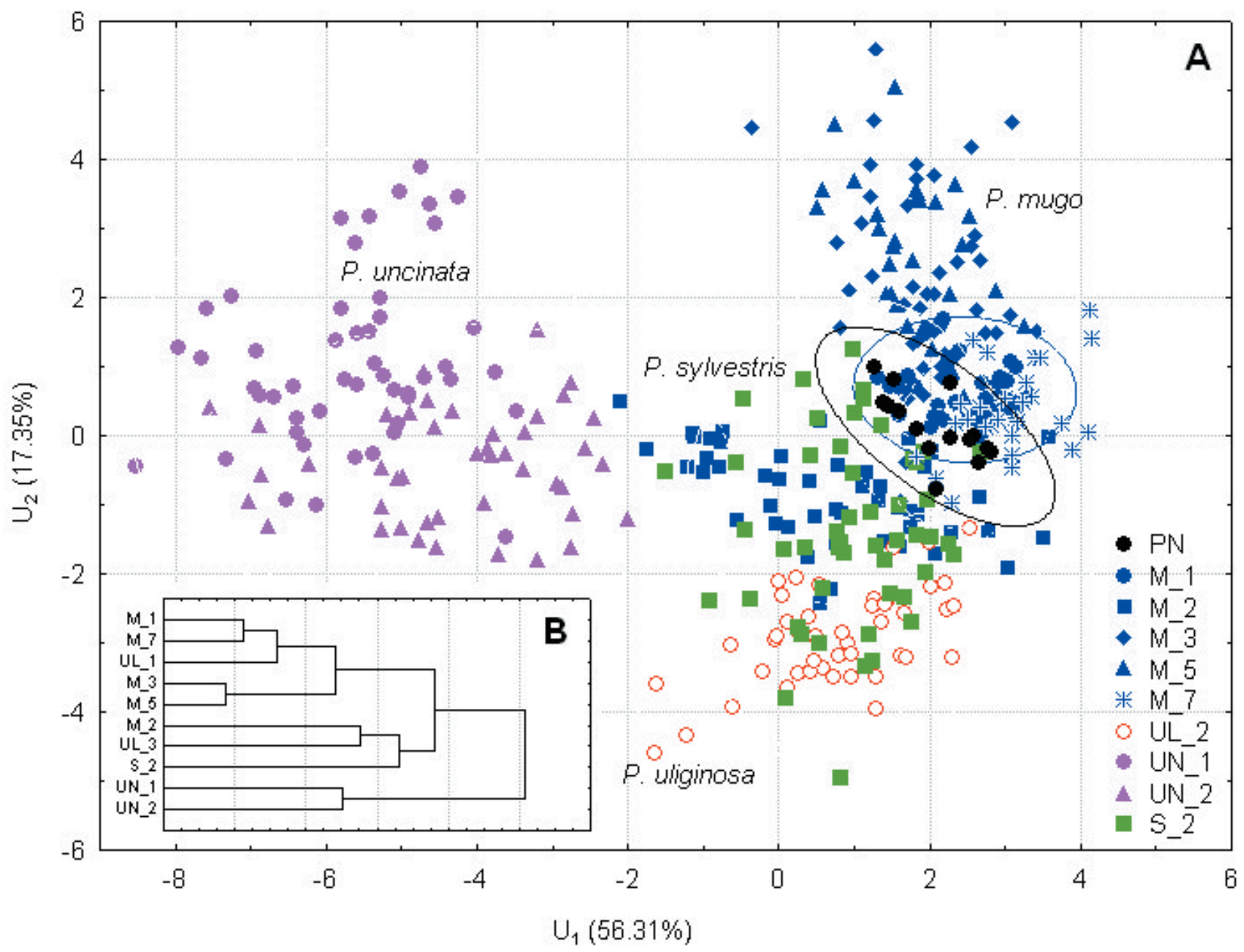

Fig. 3. Position of tree-like pines from the Mshana peat bog (PN) among the compared $P$. sylvestris (S_2), P. mugo (M_1, M_2, M $\_3, \mathrm{M} \_5$ and M $\_7$ ), $P$. uliginosa (UL_1 and UL_3) and $P$. uncinata (UN_UN_1 and UN_2) on the scatter-plot showing results of discriminant analysis (A) and on the dendrogram constructed on the shortest Euclidean distances according to Ward's method (B), based on the cone characters.

populations. The populations of $P$. uncinata were separated from all other taxa, but were also not closely related to each other (Fig. 3B). Tree-like pines from the Mshana peat bog were placed among $P$. mugo populations, close to the population of $P$. mugo from the Mshana peat bog. $P$. uliginosa seemed similar to the population of $P$. mugo from the East Carpathians, and $P$. sylvestris from the lowland of Poland is also similar to $P$. mugo/P. uliginosa.

\section{DISCUSSION}

The needles of tree-like pines and P. mugo from the Mshana peat bog in the Gorgany Mountains differed significantly on several characteristics, including number of stomata rows on the convex (abaxial) side of the needle, number of stomata rows on the flat (adaxial) side of the needle, number of resin canals, number of sclerenchyma cell layers over the vascular bundles, percentage of intermediate and thin walled sclerenchyma cells between the vascular bundles and the characteristics of the sclerenchyma cells around the resin canals (characters 2, 5, 6, 14, 21C, 21D, 22A, $22 \mathrm{~B}$ and $22 \mathrm{C}$, respectively). All other analysed characters showed no differences between the compared populations (Table 2). In the Sudetes, needle length and width, number of stomata rows on the flat (adaxial) side of the needle, ne- edle thickness, distance between vascular bundles, thickness of epidermal cells, stomatal rows ratio, needle thickness/width ratio, epidermis cell width/thickness ratio and percentages of all types of sclerenchyma cells around the resin canals and between vascular bundles (character 1, 7, $3,8,9,10,16,18,20$ and $21 \mathrm{~A}, 21 \mathrm{~B}$, respectively) also revealed statistically significant differences between $P$. mugo and P. uliginosa (Boratyńska et al. 2003; Boratyńska and Boratyński 2007; Boratyńska and Lewandowska 2009). This indicates a higher level of similarity between tree-like pines and shrub of $P$. mugo from the Mshana peat bog, than of $P$. uliginosa and $P$. mugo in the Sudetes. This was also visible in the discrimination analysis (Fig. 2A) and UPGMA dendrogram (Fig. 2B). Even smaller differences in cone characteristics were found between tree-like pines and shrubs of $P$. mugo from the Mshana peat bog (Fig. $3 \mathrm{~A}$ and $3 \mathrm{~B}$ ). Additionally, the range of variations in needle and cone characters of tree-like pines population is much more restricted compared with the variation of the other taxa (Fig. 2A and 3A). The 95\% confidence intervals of dispersion of tree-like individuals from the Mshana peat bog based on the characters of needles (Fig. 2A) and cones (Fig. 3A) are about a half as broad as for the other populations compared.

The restricted range of variation of tree-like pine population might indicate an ancient founder effect. A reduction 
of differences between this population and nearby $P$. mugo might be because of gene flow from the latter species. However, this hypotheses will need to be verified using molecular methods, if markers that allow us to distinguish between $P$. mugo and $P$. uliginosa could be found.

Several characters of needles of tree-like individuals from the Gorgany Mountains have values typical for $P$. uliginosa, intermediate values of the character among all three compared populations of the latter species or are close to one of them (compare Table 2 and data from Boratyńska et al. 2003; Boratyńska and Boratyński 2007; Boratyńska and Lewandowska 2009). The length, width and thickness of needles and distance between vascular bundles (characters $1,7,8$ and 9, respectively) have values intermediate among the three populations of peat bog pine, which can be treated as typical for $P$. uliginosa. The percentages of particular types of sclerenchyma cells between vascular bundles were also similar to those observed in $P$. uliginosa, whereas around the resin canals in the population of tree-like individuals a higher frequency of fibre-like cells were observed (compare Table 2 and data from Boratyńska and Boratyński 2007; Boratyńska and Lewandowska 2009).

Cones of tree-like individuals from the Ukraine are more symmetrical than cones of $P$. uliginosa from the Węgliniec nature reserve and have a higher number of scales with thicker, longer and wider apophyses (Marcysiak et al. 2003). The cones collected from the Mshana tree-like individuals were more similar to cones of $P$. mugo than to cones of $P$. uliginosa.

The analyses performed on cone characters did not allow to include the investigated tree-like individuals of pines in the Gorgany Mountains into taxon of $P$. uliginosa. Their origin from the ancient hybridisation between $P$. mugo and $P$. sylvestris should be also excluded. The characters of needles place them among $P$. uliginosa and close to $P$. mugo, but far from $P$. sylvestris. The closest connections of the examined tree-like individuals with $P$. uliginosa regarding needle characters suggest their identity with the latter taxon, but the characters of cones are more similar to cones of $P$. mugo. All these intermediate characteristics can be interpreted as a trace of ancient migration of $P$. uliginosa and then hybridisation with $P$. mugo. The latter process reduced expression of some morphological characters, conserving another, similarly as in the case of $P$. uncinata in the Giant Mountains (Boratyńska et al. 2009). It is note worthy, that mountain pine with hooked apophyses has been recorded from the Gorgany Mountains by Trampler (1937), who named them "Pinus uncinata rotundata gibba Wilk." (Trampler 1937: 33-34). These data have not been confirmed (Tsaryk et al. 2006), but the genes of $P$. uliginosa can be conserved in their progeny. The tree-like growth form and characters of the needles of some number of mountain pine on the Mshana peat bog indicate an influence of the genes of latter taxon, however, it can not be determined as typical $P$. uliginosa. The locality on the Mshana peat bog can be treated as relict from the time of the end of last glaciation and early Holocene (Obidowicz 1996).

The possibility of migration of mountain species, to which $P$. uliginosa can be included, from the West to East Carpathians has been confirmed by verifying the DNA variation of Abies alba (Gömöry et al. 2004; Liepelt et al. 2009).

\section{LITERATURE CITED}

BASTL M., ŠTECHOVA T., PRACH K. 2009. Effect of disturbance on the vegetation of peat bogs with Pinus rotundata in the Třeboň Basin, Czech Republic. Preslia 81: 105-117.

BORATYŃSKA K., BOBOWICZ A.M 2000. Variability of $P i-$ nus uncinata Ramond ex DC. as expressed in needle traits. Dendrobiology 45: 7-16.

BORATYŃSKA K., BORATYŃSKI A. 2007. Taxonomic differences among closely related pines Pinus sylvestris, $P$. mugo, $P$. uncinata, $P$. uliginosa as revealed in needle sclerenchyma cells. Flora 202: 555-569.

BORATYŃSKA K., BORATYŃSKI A., LEWANDOWSKI A. 2003. Morphology of Pinus uliginosa (Pinaceae) needles from populations exposed to and isolated from the direct influence of Pinus sylvestris. Bot. J. Linn. Soc. 142: 83-91.

BORATYŃSKA K., JASIŃSKA A.M., SOBIERAJSKA K., BORATYŃSKI A. 2009. A trace of ancient migration of $P$. uncinata (Pinaceae) in the Karkonosze Mts (SW Poland)? In: Z. Mirek et al. (eds), Rare, relict and endangered plant species in Poland. W. Szafer Institute of Botany, Polish Academy of Science, Kraków.

BORATYŃSKA K., LEWANDOWSKA D. 2009. Differences among three populations of Pinus uliginosa and their relation to $P$. sylvestris as expressed by the needle characters. Dendrobiology 61: 37-46.

BORATYŃSKA K., MUCHEWICZ E., DROJMA M. 2004. Pinus mugo Turra geographic differentiation based on needle characters. Dendrobiology 51: 9-16.

BUSINSKÝ R. 1999. Taxonomická studie agregátu Pinus mugo a jeho hybridnich populaci. Acta Průhoniciana 68: 123-144.

BUSINSKÝ R. 2008. The genus Pinus L. contribution and knowledge. Acta Průhoniciana, 88: 1-126.

BUSINSKÝ R., Kirschner J. 2006. Nomenclatural Notes on the Pinus mugo complex in Central Europe. Phyton 46: 129-139.

CHRISTENSEN K.I. 1987. Taxonomic revision of the Pinus mugo complex and $P . \times$ rhaetica $(P$. mugo $\times P$. sylvestris $)($ Pinaceae). Nordic J. Bot. 7: 383-408.

CHRISTENSEN K.I., DAR G.H. 1997. A morphometric analysis of spontaneous and artificial hybrids of Pinus mugo $\times$ sylvestris (Pinaceae). Nordic J. Bot. 17: 77-86.

CHRISTENSEN K.I., DAR G.H. 2003. A morphometric study of hybridization between Pinus mugo and P. sylvestris (Pinaceae). Acta Horticult. 615: 211-219.

DANIELEWICZ W., ZIELIŃSKI J. 2000. Ochrona sosny błotnej Pinus uliginosa Neumann na terenie Borów Dolnośląskich. Przegląd Przyrodniczy 11 (2-3): 113-124.

GOŁĄB Z. 1999. Sosna błotna (P. uliginosa Neumann) na Wielkim Torfowisku Batorowskim w Górach Stołowych. Szczeliniec 3: 41-48.

GÖMÖRY D., LONGAUER R., LIEPELT S., BALLIAN D., BRUS R., KRAIGHER H., PARPAN V. I., PARPAN T.V., PAULE L., STUPAR V. I., ZIEGENHAGEN B. 2004. Variation patterns of mitochondrial DNA of Abies alba Mill. in suture zones of postglacial migration in Europe. Acta Soc. Bot. Pol. 73(3): 203-206.

JASIŃSKA A.K., IAKUSHENKO D.M., SOBIERAJSKA K.I., TRETIAK P.R., ISZKUŁO G. 2009. Pinus uliginosa G.F. Neumann, a new taxon for the Ukrainian flora. Ukr. Bot. J. 66 (5): 640-646.

KORMUTÁK A., OSTROLUCKÁ M., VOOKOVÁ B., PRETOVÁ A., FEČKOVÁ M. 2005. Artificial hybridization of $P i$ nus sylvestris L. and Pinus mugo Turra. Acta Biol. Cracov., ser. Bot. 47 (1): 129-134.

LIEPELT S., CHEDDADI R., DE BEAULIEU J.L., FADY B., GÖMÖRY D., HUSSENDÖRFER E., KONNERT M., LITT T., LONGAUER R., TERHÜRNE-BERSON R., ZIEGENHAGEN B. 2009. Postglacial range expansion and its genetic imprints in 
Abies alba (Mill.) - A synthesis from palaeobotanic and genetic data. Rev. Palaeobot. Palynol. 153: 139-149.

MACH J., LANTA V., BASTIL M. 2009. The effect of mining and vegetation scarification on the survival and establishment of Pinus rotundata Link and $P$. sylvestris L. in contrasting peat bog habitats. Pol. J. Ecol. 57 (2): 239-250.

MARCYSIAK K. 2004. Interpopulations variability of Pinus uncinata Ramond ex DC. in Lam. \& DC. (Pinaceae) cone characters. Dendrobiology 51: 43-51.

MARCYSIAK K., BORATYŃSKA K., MAZUR M. 2003. Variability of Pinus uliginosa cones from the peat-bog in Węgliniec. Dendrobiology 49: 43-47.

MARCYSIAK K., BORATYŃSKI A. 2007. Contribution to the taxonomy of Pinus uncinata (Pinaceae) based on cone characters. Pl. Syst. Evol. 264: 57-73.

OBIDOWICZ A. 1996. A late Glacial-Holocene history of the formation of vegetation belts in the Tatra Mts. Acta Palaeob. 36: 159-206.

SCHRAMM W. 1925. Nieznane stanowiska kosodrzewiny w Karpatach Środkowych. Kosmos 50 (4): 1340-1451.

SCHRAMM R.W. 1973. Obecny stan występowania kosodrzewiny (Pinus montana s.l.) w Karpatach Polskich na wschód od Tatr. Fragm. Flor. Geobot. 19: 23-37.

SOBIERAJSKA K., BORATYŃSKA K. 2008. Variability of needle characters of Pinus mugo Turra populations in the Karkonosze Mountains in Poland. Dendrobiology 59: 41-49.

SOBIERAJSKA K., BORATYŃSKA K. 2010. Variability of $P i$ nus mияo Turra (Pinaceae) populations in the Giant mountains (Karkonosze, Sudetes) on the basis of cone characters. Dendrobiology (in press).

SOKAL R.R., ROHLF F.J. 2003. Biometry (third edition). W. H. Freeman and Company New York.
STANISZ A. 2007. Przystępny kurs statystyki z zastosowaniem Statistica PL na przykładach z medycyny. Kraków.

STASZKIEWICZ J. 2001. Pinus Xrhaetica Brügger. In: R. Kaźmierczakowa, K. Zarzycki (eds), Polska Czerwona Księga Roślin, 65-66. W. Szafer Institute of Botany Polish Academy of Sciences, Kraków

STASZKIEWICZ J., TYSZKIEWICZ M. 1969. Naturalne mieszańce $P$. mugo Turra $\times$ Pinus sylvestris L. w Kotlinie Nowotarskiej. Fragm. Flor. Geobot. 15(2): 187-212.

STASZKIEWICZ J., TYSZKIEWICZ M. 1972. Zmienność naturalnych mieszańców Pinus sylvestris $\mathrm{L} \times$ Pinus mugo Turra (=P. Xrotundata Link) w południowo-zachodniej Polsce oraz na wybranych stanowiskach Czech i Moraw. Fragm. Flor. Geobot. 18 (2): 173-191.

SZWEYKOWSKI J. 1969. The variability of Pinus mugo Turra in Poland. Bull. Soc. Amis Sci. Lett. Poznań, Ser. D, 10: 37-54.

TRAMPLER T. 1937. Kosodrzewina w Gorganach. Acta Soc. Bot. Pol., 14 (1): 1-44.

TSARYK J., DIDUKH Y.P., TASENKEVICH L., WALDON B., BORATYŃSKI A. 2006. Pinus mugo Turra (Pinaceae) in the Ukrainian Carphatians. Dendrobiology, 55: 39-49.

WACHOWIAK W., PRUS-GŁOWACKI W. 2008. Hybridisation processes in sympatric populations of pines Pinus sylvestris L., P. mugo Turra and P. uliginosa Neumann. Pl. Syst. Evol. 271: $29-40$.

WATAŁA C. 2002. Biostatystyka - wykorzystanie metod statystycznych w pracy badawczej w naukach biometrycznych. Wyd. Alfa-media press. Bielsko-Biała.

WINDAKIEWICZ E. 1873. O ważności torfowisk dla wschodniej Galicji i o torfowiskach w Nowosielicy i Strutynie przy Dolinie. Sprawozdania Komisji Fizjograficznej Akademii Umiejętności 7: 90-98. 